\title{
Characterisation of mice lacking all functional isoforms of the pro-survival BCL-2 family member A1 reveals minor defects in the haematopoietic compartment
}

\author{
Robyn L Schenk ${ }^{1,2}$, Selma Tuzlak ${ }^{2,3}$, Emma M Carrington ${ }^{1,2}$, Yifan Zhan ${ }^{1,2}$, Susanne Heinzel ${ }^{1,2}$, Charis E Teh ${ }^{1}$, Daniel H Gray ${ }^{1,2}$, Lin Tai ${ }^{1}$, \\ Andrew M Lew ${ }^{1,2}$, Andreas Villunger ${ }^{3,4}$, Andreas Strasser ${ }^{1,2}$ and Marco J Herold ${ }^{\star, 1,2}$
}

The pro-survival proteins of the BCL-2 family regulate the survival of all cells, and genetic deletion models for these proteins have revealed which specific BCL-2 family member(s) is/are critical for the survival of particular cell types. A1 is a pro-survival BCL-2-like protein that is expressed predominantly in haematopoietic cells, and here we describe the characterisation of a novel mouse strain that lacks all three functional isoforms of A1 (A1-a, A1-b and A1-d). Surprisingly, complete loss of A1 caused only minor defects, with significant, although relatively small, decreases in $\gamma \delta \mathrm{TCR} T$ cells, antigen-experienced conventional as well as regulatory CD4 $T$ cells and conventional dendritic cells (cDCs). When examining these cell types in tissue culture, only $\mathrm{cDC}$ survival was significantly impaired by the loss of A1. Therefore, A1 appears to be a surprisingly redundant pro-survival protein in the haematopoietic system and other tissues, suggesting that its targeting in cancer may be readily tolerated.

Cell Death and Differentiation (2017) 24, 534-545; doi:10.1038/cdd.2016.156; published online 13 Janaury 2017

The pro-survival proteins of the BCL-2 family prevent apoptosis $^{1}$ and studies using gene-targeted mice have revealed which cell types rely on which pro-survival protein for their survival. For example, $\mathrm{BCl}-2^{-/}$mice exhibit thymic and splenic atrophy, a loss of fur pigment and die $\sim 30$ days post birth from polycystic kidney disease, attributable to excess lymphocyte, melanocyte and renal epithelial cell apoptosis, respectively. ${ }^{2-4} \mathrm{Bcl}-\mathrm{X}^{-/-}$mice die before $\mathrm{E} 14.5$ of embryonic development because of aberrant death of erythroid and neuronal cells. ${ }^{5}$ The generation of chimaeric or tissue-specific $\mathrm{Bcl}-\mathrm{X}^{-/}$revealed a critical role for $\mathrm{BCL}-\mathrm{XL}$ in the survival of developing lymphocytes ${ }^{5}$ and platelets. ${ }^{6,7}$ $\mathrm{MCl}-1^{-/}$embryos die before implantation (E3.5), ${ }^{8}$ but conditional $\mathrm{Mcl}-1$ deletion models have demonstrated an essential role for MCL-1 in the survival of haematopoietic stem cells, lymphocytes, neurons and cardiomyocytes. ${ }^{9-15} \mathrm{Bcl}-\mathrm{W}^{-1}$ mice have impaired spermatogenesis. ${ }^{16,17}$

A1 remains the only pro-survival $B C L-2$ family member for which a knockout mouse strain has not been developed. A1 was first discovered as a GM-CSF-inducible gene with significant sequence similarity to $\mathrm{BCL}-2$ and $\mathrm{MCL}-1,{ }^{18}$ and its human homologue BFL-1 was later identified in fetal liver. ${ }^{19}$ Overexpression of A1 protected an IL-3-dependent cell line from growth factor deprivation-induced apoptosis, thus demonstrating its pro-survival function. ${ }^{20}$ In mice, $A 1$ expression is restricted to the haematopoietic compartment. ${ }^{18}$ Human BFL-1 expression is more widespread, but also predominantly haematopoietic. ${ }^{21} \mathrm{~A} 1$ can be upregulated by NF- $K B$ signalling, and it has been proposed that $A 1 / B F L-1$ is important for the survival of several activated immune cell subsets through stimulation of antigen or cytokine receptors. ${ }^{22-25}$
Studies of $A 1$ in mice are complicated by the presence of multiple isoforms that are the result of gene duplication events. Three isoforms ( $A 1-a, A 1-b$ and $A 1-d)$ are functional, whereas the fourth, $A 1-C$, is a pseudogene because of a frameshift mutation that results in an early stop codon. ${ }^{26} A 1-a,-b$ and $-d$ are nearly identical at both the DNA and protein levels, but their expression patterns vary between cell types and particular functions for each isoform are yet to be delineated. ${ }^{27}$

Mice lacking the $A 1-a$ isoform have been generated, but showed only minor defects in neutrophils and mast cells, ${ }^{28,29}$ suggesting functional redundancy between the different isoforms. Other in vivo studies of A1 involved knockdown of all functional isoforms using transgenic expression of an shRNA. ${ }^{30-33}$ A1 knockdown caused a reduction in B cells, mast cells and dendritic cells, but knockdown in these models was usually incomplete and hence not equivalent to a knockout.

Herein we describe the characterisation of a novel mouse strain lacking all A1 proteins, with a focus on the immune cell subsets that have previously been proposed to rely on $A 1$ for their survival. Our results demonstrate that complete loss of A1 has only a minor impact, with only conventional dendritic cells (cDCs) being substantially affected. These findings have important implications for the regulation of haematopoietic cell survival, and also inform on toxicities that may be expected from therapeutic targeting of $\mathrm{A} 1$.

\section{Results}

Generation of A1-deficient mice. The $A 1^{-1-}$ mouse strain was generated by sequential deletion of each $A 1$ isoform $(A 1-a, A 1-b$ and $A 1-d)$ in embryonic stem (ES) cells. The

${ }^{1}$ The Walter and Eliza Hall Institute for Medical Research, Parkville, Victoria 3052, Australia; ${ }^{2}$ Department of Medical Biology, University of Melbourne, Parkville, Victoria 3050, Australia; ${ }^{3}$ Divison of Developmental Immunology, BIOCENTER, Medical University Innsbruck, Innsbruck, Austria and ${ }^{4}$ Tyrolean Cancer Research Institute, Innsbruck, Austria

${ }^{*}$ Corresponding author: MJ Herold, The Walter \& Eliza Hall Institute for Medical Research, 1G Royal Parade, Parkville, Victoria 3050, Australia. Tel: 61393452497 ; Fax: 613-9347-0852; E-mail: herold@ wehi.edu.au

Received 14.7.16; revised 08.11.16; accepted 01.12.16; Edited by C Borner; published online 13.1.2017 
separate targeting constructs each contained a different antibiotic resistance cassette for positive selection, flanked by flippase recombination target sites (Figure 1a and Supplementary Figure S1a). The loci were targeted in the order of $A 1-a$ (Bcl2a1a), $A 1-d$ (Bcl2a1d) and then $A 1-b$ $(B c / 2 a 1 b)$. This third targeting introduced a loxP-flanked allele of $\mathrm{Bcl} 2 \mathrm{a} 1 \mathrm{~b}$ to allow for its conditional deletion. Antibiotic resistance markers were removed by flippase-mediated recombination to yield the conditional $A 1$ knockout allele $\left(A 1^{f f}\right)$ that lacks Bcl2a1a and Bcl2a1d but has Bcl2a1b flanked by loxP sites. Two independent ES cell clones were used to generate the $A 1$-deficient mice. $A 1^{f l /+}$ mice were crossed with $C M V-C r e^{T /+}$ mice, in which the CRE recombinase is expressed ubiquitously and constitutively. This produced the final knockout allele $\left(A 1^{-}\right)$. Intercrossing of $A 1^{+/-}$mice generated the complete knockout mice $\left(A 1^{-/-}\right)$.

a



$B c / 2 a 1 d$ and $B c / 2 a 1 a$ constitutive $\mathrm{KO} / \mathrm{Bc} / 2 \mathrm{a} 1 \mathrm{~b}$ conditional KO allele (after Flp recombination):

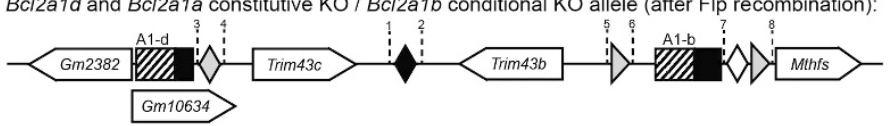

$B c / 2 a 1 d, B c / 2 a 1 a$ and $B c / 2 a 1 b$ constitutive KO allele (after Cre recombination):

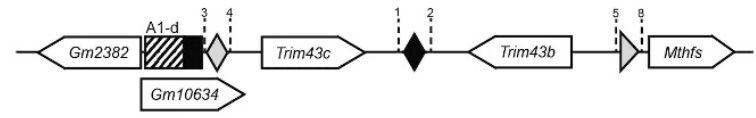

b

T cells

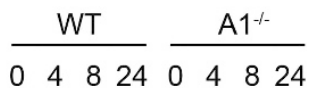

$26-\cdots-\cdots-1-\mathrm{BCL}-\mathrm{XL}$

$25-\cdots-\cdots-\cdots B-2$

17-

35- $-\div-+\div-\div$ MCL-1

70-- - - - - HSP70

C

$\alpha-C D 3+\alpha-C D 28$

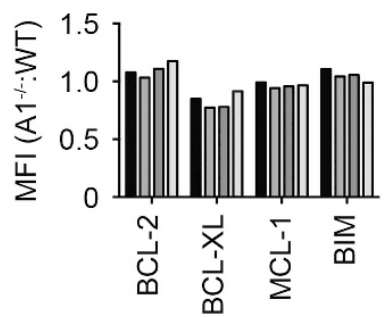

B cells

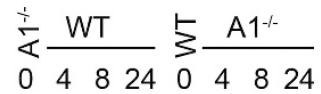

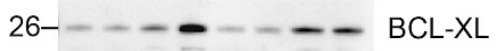

25- - - - - - BCL-2

17- $-\infty \quad \mathrm{A} 1$

$35--\cdots+-\cdots--M C L-1$

70- - - - - - HSP70

$\alpha-\lg M$

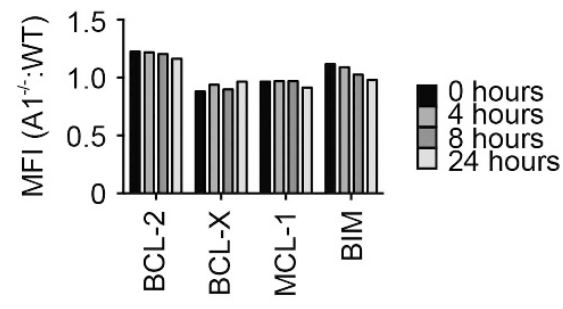

Figure 1 For caption see page 536 
Deletion of all $A 1$ isoforms was confirmed by PCR using primers for each individual locus (Figure 1a, Supplementary Figure S1c and Supplementary Table S2). $A 1^{-1-}$ mice were born at the expected Mendelian frequency (Supplementary Table S1) and proved fertile. They appeared outwardly normal up to 12 months of age and are currently being monitored further.

Western blotting was performed on activated $B$ and $T$ lymphocytes, stimulated with anti-IgM fragments or antibodies against CD3 and CD28, respectively, from wild-type and $\mathrm{A} 1^{-/-}$ spleen using an A1-specific monoclonal antibody that recognises all three functional isoforms. ${ }^{34}$ In wild-type cells, $\mathrm{A} 1$ was markedly upregulated by $4 \mathrm{~h}$ of stimulation, whereas no protein was detected in A1-deficient cells. This analysis showed no detectable compensatory upregulation of the other pro-survival BCL-2 family proteins, BCL-2, BCL-XL and MCL-1, in A1-deficient cells (Figure 1b). We further quantitated the other pro-survival proteins by intracellular FACS staining of stimulated lymphocytes (Figure 1c and Supplementary Figure S1d). The ratios of the mean fluorescence intensities (MFIs) for the $A 1^{-/-}$to wild-type cells centred around 1 (Figure 1c), demonstrating that there was no appreciable up- or downregulation of any of these BCL-2 family proteins in the A1-deficient cells. The strong upregulation of $B C L-X L$ in response to $B$ cell receptor $(B C R)$ or $T$ cell receptor (TCR) stimulation verified that the cells had been successfully activated (Supplementary Figure S1e). Together, these results demonstrate that our newly engineered $A 1^{-1-}$ mice lack all $A 1$ protein forms and they also show that $A 1$ is not essential for embryonic development.

\footnotetext{
A1-deficient mice have no defects in the B lymphocyte lineage. $A 1$ has been postulated to be involved in $B$ cell maturation based on the observation that pre-B cells lacking the kinase PDK1 undergo excess apoptosis that is correlated with the loss of $A 1$ mRNA. Retroviral expression of $\mathrm{A} 1$ protected these knockout cells from apoptosis. ${ }^{35}$ We determined the percentages and total numbers of pro/pre-, immature, transitional and mature $B$ cell subsets in the bone marrow of $A 1^{-1-}$ mice by flow cytometry, but found no significant differences compared with wild-type mice (Figure 2a and Supplementary Figure S2a).

In the A1 shRNA knockdown mice, there was a small reduction in follicular $B$ cells in the spleen. ${ }^{30}$ Subsequent studies using a conditional knockdown mouse model similarly showed that loss of $A 1$ caused a reduction in the follicular $B$ cell subset. ${ }^{32}$ However, we found that the follicular as well as
}

marginal zone $B$ cell subsets in the spleen were comparable between the wild-type and $A 1^{-/-}$mice (Figure $2 \mathrm{~b}$ and Supplementary Figure S2b). There was a trend towards a reduction in B1a cells in the lymph nodes of the $A 1$ knockout mice (Supplementary Figure S2b), prompting us to investigate the B1 cell subsets in their preferred niche, the peritoneal cavity. Gating on $\mathrm{CD}_{19^{+}}$cells, the three different B cell compartments could be discriminated as conventional B2 $\left(\mathrm{CD}_{4} 3^{-} \mathrm{CD}^{-}\right)$, B1a $\left(\mathrm{CD}^{+}\right)$, or $\mathrm{B1b}$ cells $\left(\mathrm{CD} 43^{+} \mathrm{CD} 5^{-}\right)$. There were no differences in any of these $B$ cell subsets between the wild-type and $A 1^{-/-}$mice (Supplementary Figure S2c).

A1 was proposed to play a role in the survival of activated $B$ cells. ${ }^{36,37}$ Accordingly, in the $A 1$ shRNA knockdown mice, purified T2 and follicular B cells underwent increased BCR activation-induced apoptosis in culture. ${ }^{30}$ We found that BCRstimulated $B$ cell blasts from wild-type and $A 1^{-/-}$mice underwent similar activation-induced apoptosis in vitro (Figure 2c). Collectively, these findings demonstrate that complete loss of A1 does not cause marked defects in the $B$ lymphoid lineage, at least within the conditions examined.

\begin{abstract}
A1-deficient mice have a reduction in $\gamma \delta T C R$ T cells and memory $\mathrm{CD4}^{+} \mathrm{T}$ cells but otherwise have a normal $\mathrm{T}$ cell compartment. A1 expression is markedly upregulated in immature $T$ cells during the process of pre-TCR selection, ${ }^{38,39}$ suggesting that $\mathrm{A} 1$ may promote cell survival during this critical developmental stage. Accordingly, the A1 knockdown mouse model had an increase in DN2 and DN3 thymocytes and a corresponding reduction in the DN4 and DP populations. ${ }^{30}$ Flow cytometric analysis revealed that $\mathrm{T}$ cell development proceeded normally in $A 1^{-/}$mice, with no reductions seen in the DN1-4 progenitors, immature DP thymocytes or mature $\mathrm{CD}^{+}$or $\mathrm{CD}^{+}$populations compared with wild-type controls (Figure $3 a$ and Supplementary Figure S3a). Moreover, when $A 1^{-1-}$ thymocytes were treated in culture with apoptosis-inducing agents (etoposide, PMA, dexamethasone, ionomycin or the BCL-2/BCL-XL/BCL-W inhibiting $\mathrm{BH} 3$ mimetic $\mathrm{ABT}-737)$, they died at a rate comparable to wild-type thymocytes (Figure $3 b$ and Supplementary Figure S3b).

TCR stimulation was shown to cause an increase in A1 protein in mature $T$ cells, ${ }^{40,41}$ suggesting that $A 1$ may play a critical role in activated $T$ cell survival. Our flow cytometric analysis revealed a small but significant decrease in the unconventional TCR $\gamma \delta$ T cell population, but no differences were seen in the conventional TCR $\alpha \beta$ T cells, including both
\end{abstract}

Figure 1 Generation and validation of $A 1$-deficient mice. (a) Schematic representation of the murine $A 1$ gene locus and the three targeting constructs for $A 1$-a (Bcl2a1a), $A 1-d(B c / 2 a 1 d)$ and $A 1-b(B c / 2 a 1 b)$. F5, FRT and F3 sites were targets for Flpe-mediated recombination to remove the antibiotic resistance cassettes, once all three targeting constructs had been inserted. Bcl2a1a and Bcl2a1d are constitutively deleted after Flpe recombination, and Bcl2a1b is flanked by loxP sites. Intercrossing mice carrying the conditional knockout allele with the CMV-Cre transgenic mouse enabled CRE-mediated recombination to remove Bcl2a1b for the constitutive knockout. The lox5171 and attB or attP sites were used for diagnostic in vitro deletion tests through the multiple rounds of gene targeting. Numbers and dotted lines indicate sites for PCR primers, described in Supplementary Table S2. (b) FACS-sorted Tand B lymphocytes from the spleens of wild-type and $A 1^{-/-}$mice were stimulated in vitro for the times indicated and cell lysates were then prepared for western blotting. T cells were treated with antibodies against CD3 and CD28. B cells were treated with anti-lgM antibody fragments in the presence of IL-4 and IL-5. Per lane, $20 \mu \mathrm{g}$ of protein was loaded. Probing for HSP70 was used as a protein loading control. Image is representative of three independent experiments. (c) Intracellular FACS staining for the indicated BCL-2 family proteins after B or T cell stimulation. Bar graphs represent the mean fluorescence intensity (MFI) ratio of $A 1^{-1-} /$ wild-type cells for each pro-survival or pro-apoptotic protein at 0, 4, 8 and $24 \mathrm{~h}$ after stimulation with anti-lgM antibody fragments $\left(\mathrm{B}_{2} 2 \mathrm{O}^{+}\right.$cells depicted) or anti-CD3 + anti-CD28 antibodies (B220 cells depicted). Ratios are determined from the average MFIs of cells stimulated from three mice of each genotype 
a
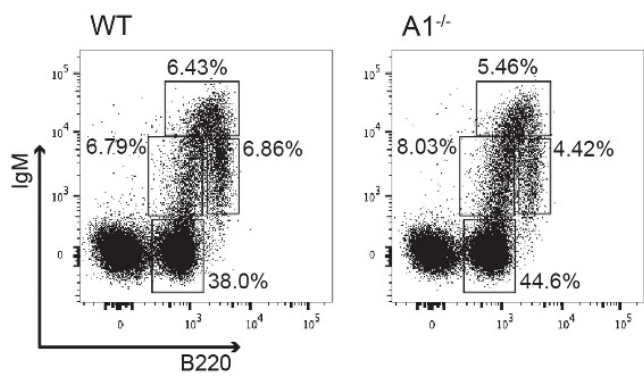

b
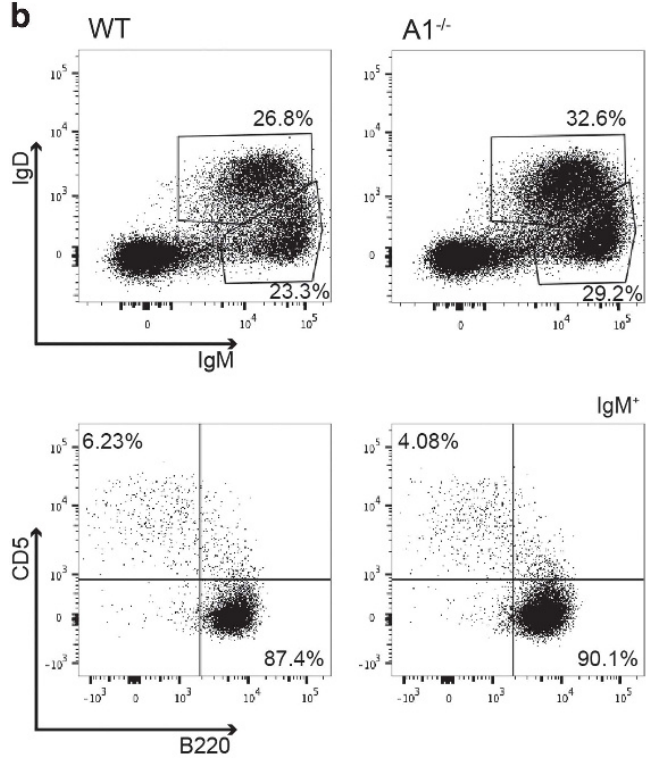

C

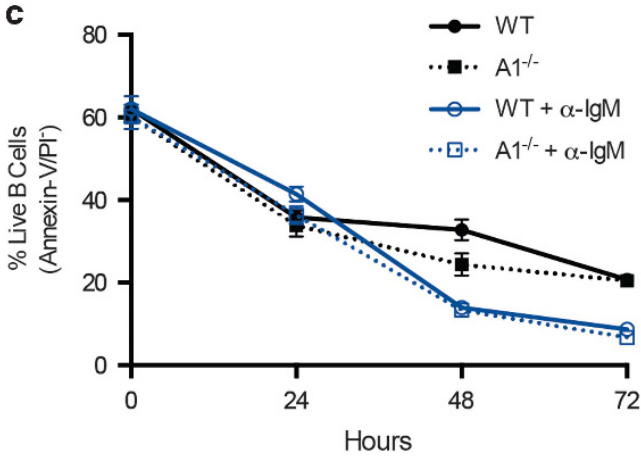

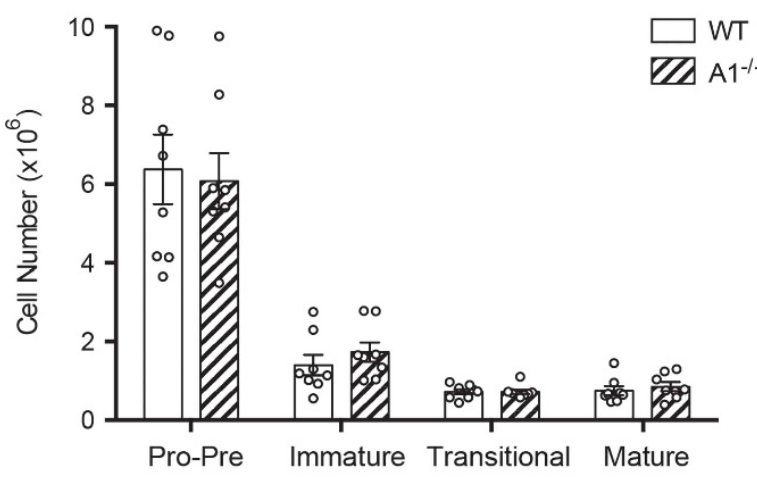

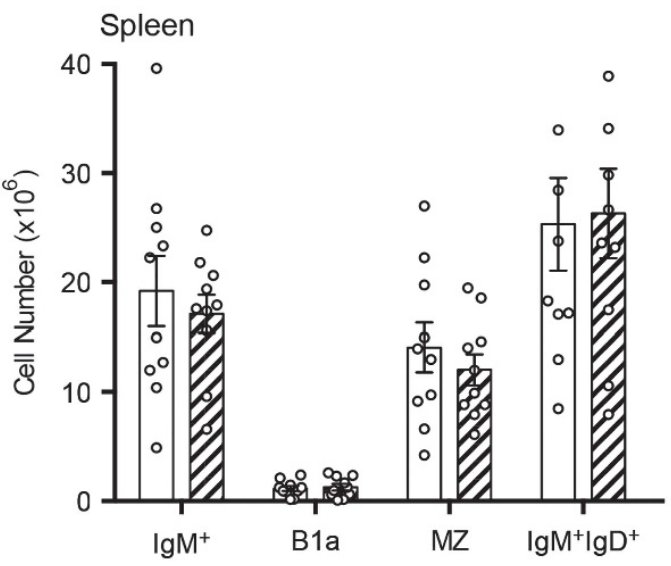

Figure $2 A 1$ deletion does not affect $B$ lymphocytes. (a, left) Representative FACS plots of $B$ cell populations in the bone marrow, defined as pro/pre $\left(B 220^{+}\right.$IgM $\left.{ }^{-}\right)$, immature

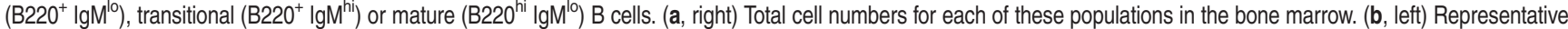
FACS plots of $\mathrm{B}$ cell populations in the spleen. IgM ${ }^{+}$cells are further subclassified as marginal zone $\left(\mathrm{B} 22 \mathrm{O}^{+} \mathrm{CD}^{-}\right)$or $\mathrm{B} 1 \mathrm{a}\left(\mathrm{CDF}^{+} \mathrm{B} 22 \mathrm{O}^{-}\right) \mathrm{B}$ cells. (b, right) Cell numbers quantified for each of these populations in the spleens of wild-type and $A 1^{-/-}$mice. (c) Unsorted splenocytes from wild-type and $A 1^{-/-}$mice were put into culture and stimulated with $2 \mu \mathrm{g} /$ $\mathrm{ml}$ anti-IgM antibody fragments. Apoptosis of $\mathrm{B}_{22} \mathrm{O}^{+}$cells was followed over time by Annexin-V and PI staining and flow cytometric analysis. Data are representative of four mice for each genotype, with each treatment performed in triplicate

the $\mathrm{CD}^{+}$and $\mathrm{CD}^{+}$populations (Figure $4 \mathrm{a}$ and Supplementary Figure S4a). However, the proportions of a unique subpopulation of $\mathrm{CD} 4^{+} \mathrm{T}$ cells, the $\mathrm{FOXP}^{+}$regulatory $T$ cells $\left(T_{\text {reg }}\right)$, were found to be significantly decreased in the thymus and spleen of A1-deficient mice (Supplementary Figure S4b). By total cell numbers, this was only significant in the spleen (Figure 4b). A closer examination of $\mathrm{T}$ cell activation profiles on $\mathrm{CD}^{+} \mathrm{T}$ cells uncovered a significant decrease in the central memory (CD62 $\left.\mathrm{L}^{\text {hi }} \mathrm{CD} 44^{+}\right)$and effector memory $\left(\mathrm{CD}_{2} \mathrm{~L}^{\mathrm{lo}} \mathrm{CD} 44^{+}\right.$) populations in the $A 1^{-1-}$ mice (Figure 4c). Although these analyses were conducted in naive mice (not experimentally challenged with a pathogen or immunogen), upregulation of CD44 and downregulation of $\mathrm{CD62} \mathrm{L}$ are indicative of $\mathrm{T}$ cells that have been antigen 
a
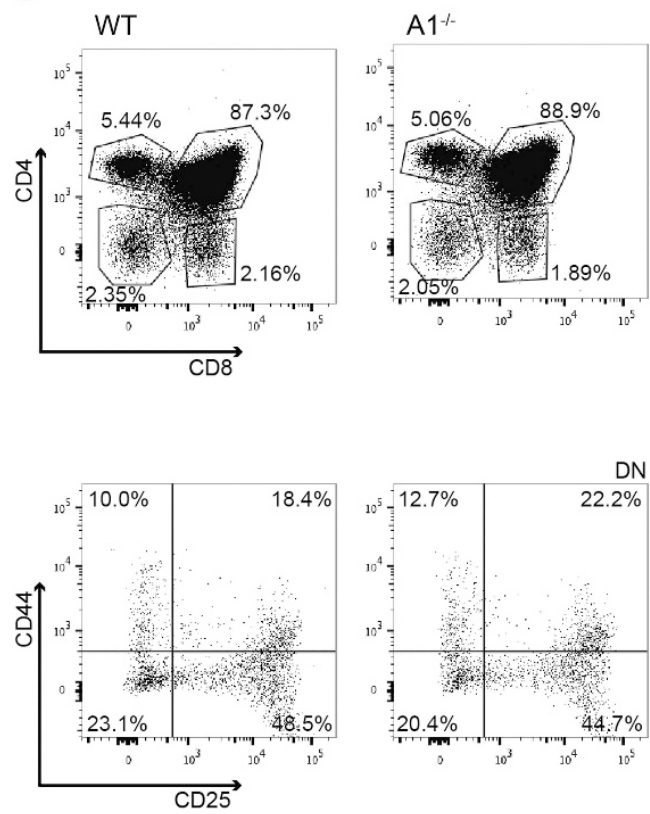
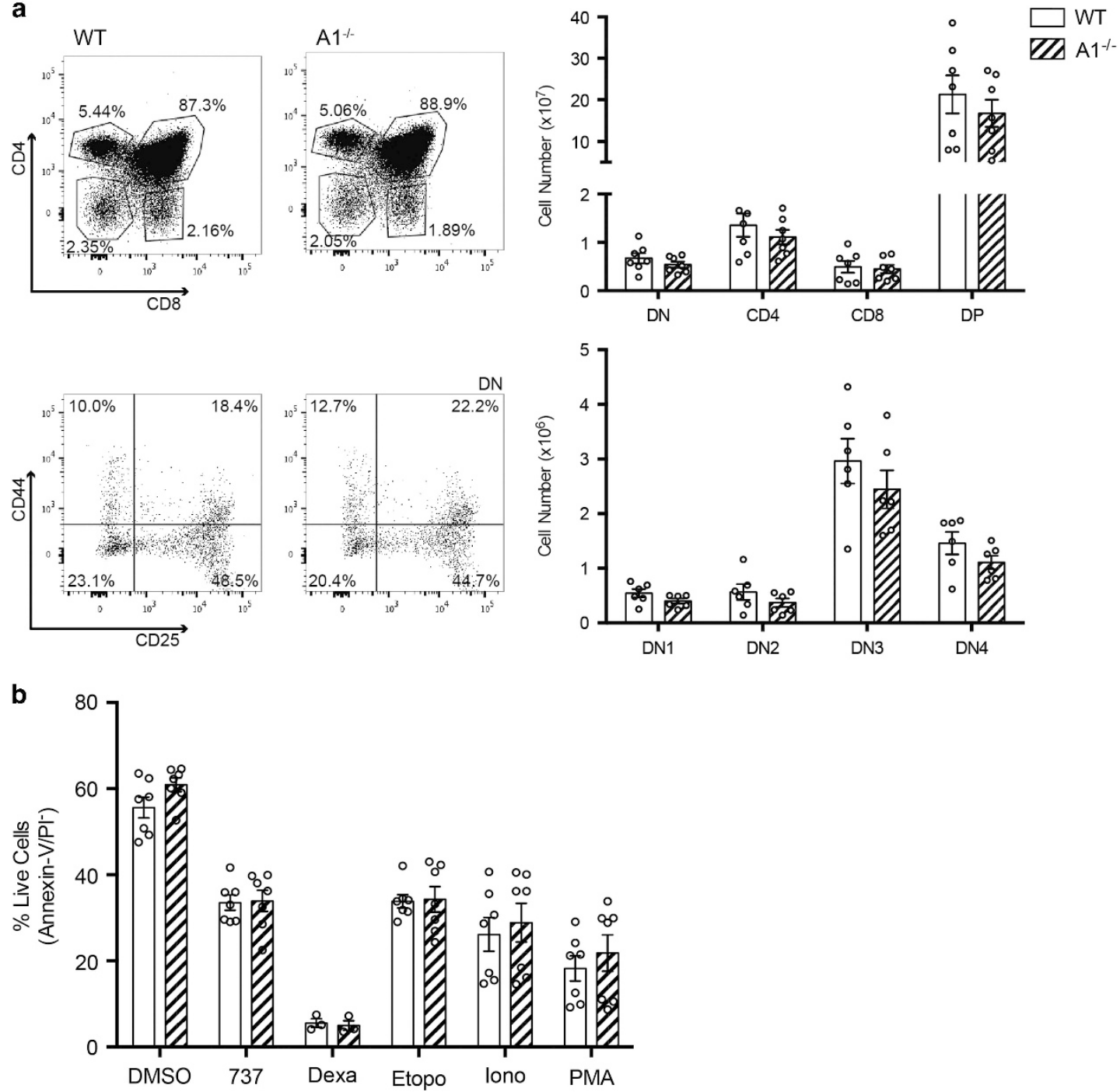

Figure 3 T cell development and stress-induced apoptosis are normal in $A 1^{-/-}$mice. (a, left) Representative FACS plots of developing T cells in the thymus of wild-type and $A 1^{-1-}$ mice. T cells develop in the thymus from the CD4/CD8 double-negative (DN) stage, becoming double positive (DP) and then differentiating into either CD4 or CD8 single-

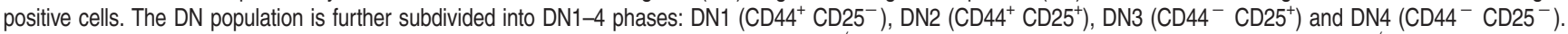
(a, right) Quantified total cell numbers for developing T cell populations in wild-type and $A 1^{-1}$ mice. (b) Thymocytes harvested from wild-type and $A 1^{-1-}$ mice were put into culture with the following apoptosis-inducing compounds: ABT-737 (737) $0.5 \mu \mathrm{M}$, dexamethasone (Dexa) $0.5 \mathrm{ng} / \mathrm{ml}$, etoposide (Etopo) $0.5 \mu \mathrm{g} / \mathrm{ml}$, ionomycin (lono), $0.1 \mu \mathrm{g} / \mathrm{ml}$, PMA $0.5 \mathrm{ng} / \mathrm{ml}$ or DMSO as a control. Apoptosis was assessed by FACS analysis after staining with fluorochrome-conjugated Annexin-V and PI (5 $\mu \mathrm{g} / \mathrm{ml})$ at $24 \mathrm{~h}$ post treatment. Data are representative of six mice for each genotype, with each treatment performed in triplicate

exposed. No loss of memory cells was observed in the $C D 8^{+} T$ cell population (Supplementary Figure S4c). Interestingly, the central memory- and effector memory-like $T_{\text {reg }}$ populations in the spleen were also reduced in the $A 1$-deficient mice (Figure 4c). Therefore, the reduction of the $\mathrm{CD} 44^{+}$memory phenotype populations appears to be specific to $\mathrm{CD} 4^{+} \mathrm{T}$ cells.

To study the role of $\mathrm{A} 1$ in the activated $\mathrm{T}$ cells, $\mathrm{CD} 4^{+}$cells were isolated from $A 1^{-1-}$ and wild-type mice and subjected to stimulation with CD3 antibodies alone or in combination with CD28 antibodies or IL-2. Perhaps surprisingly, there was no discernable difference in proliferation, rate of cell division or survival between $\mathrm{T}$ cells from $A 1^{-/}$and wild-type mice (Figure 4d and Supplementary Figure S4d).

Thus, the only $\mathrm{T}$ cell populations that are slightly affected by the loss of $A 1$ are the TCRy $\delta$ T cells, the physiological impact of which has not been explored, and $\mathrm{T}_{\text {reg }}$ cells as well as conventional $\mathrm{CD} 4^{+} \mathrm{T}$ cells with a $\mathrm{CD} 44^{+}$ memory phenotype.

Loss of $A 1$ decreases the numbers of $\mathrm{CDCs}$ and impairs their survival in vitro, but has no impact on other innate immune cell types. Neutrophils from mice lacking the A1-a isoform exhibited abnormally increased apoptosis in culture. $^{28}$ Similarly, $A 1$ shRNA knockdown mice had a reduction in granulocytes. ${ }^{30} \mathrm{~A}$ combined dependency on both $\mathrm{A} 1$ and MCL-1 was recently revealed in neutrophils, but in particular A1 expression was dramatically increased upon stimulation with either LPS or GM-CSF. ${ }^{42}$ We therefore examined the impact of complete A1 loss on granulocyte numbers in vivo and on their survival in culture. At steady 
a

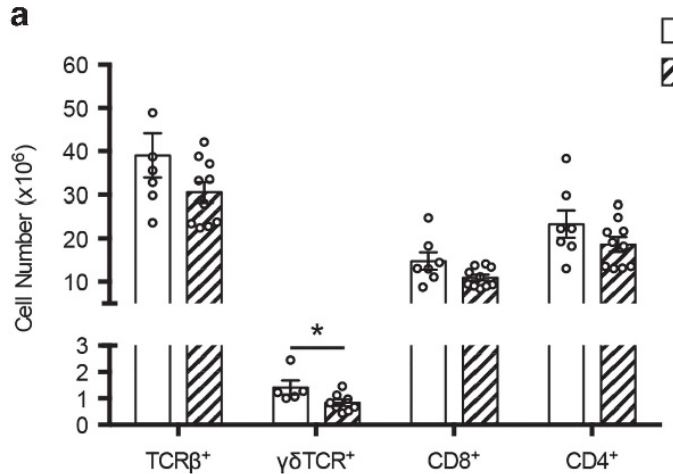

c
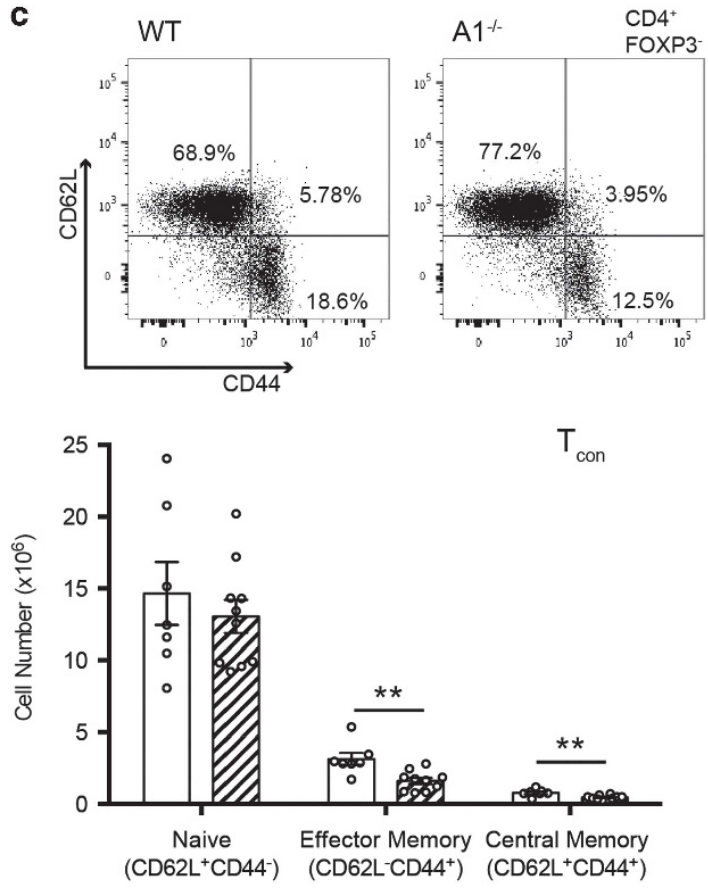

$\left(\mathrm{CD} 62 \mathrm{~L}^{+} \mathrm{CD} 44\right)$ $\square \mathrm{WT}$

b

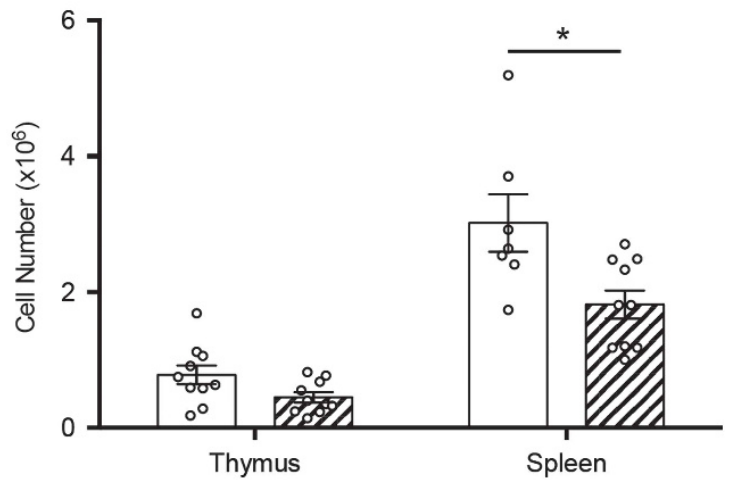

d

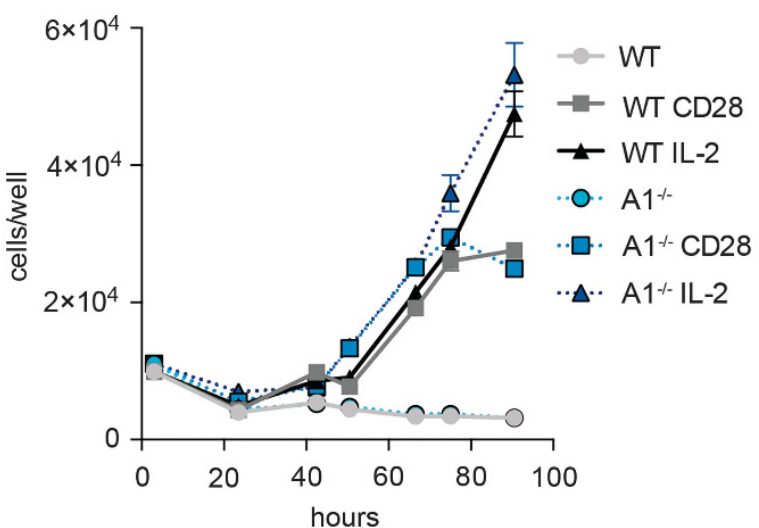

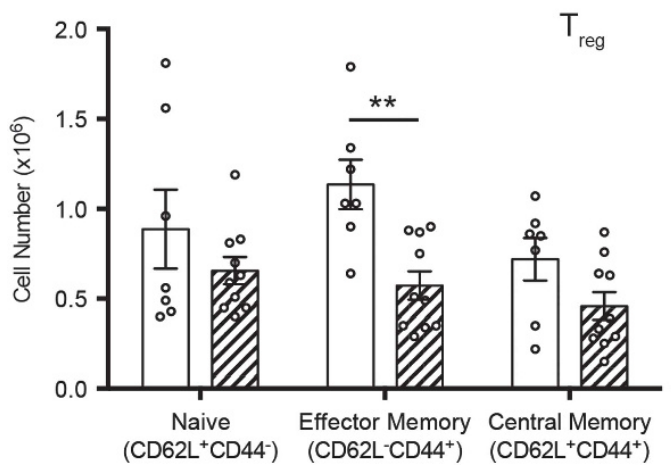

Figure $4 \mathrm{TCR} \gamma \delta \mathrm{T}$ cells, regulatory $\mathrm{T}$ cells and memory $\mathrm{CD} 4^{+} \mathrm{T}$ cell populations are reduced in A1-deficient mice. (a) Total cell numbers of $\mathrm{T}$ cell populations as determined by flow cytometric analysis of spleen cells from wild-type and $A 1^{-/-}$mice. (b) Total numbers of $\mathrm{CD} 4^{+} \mathrm{FOXP} 3^{+}$regulatory $\mathrm{T}$ cells in the thymus and spleen of wild-type and $A 1^{-/-}$ mice, as determined by flow cytometry. (c, top) Representative T cell activation profiles of $\mathrm{CD4}^{+}{ }^{+}$FOXP3 ${ }^{-}$conventional $\mathrm{T}$ cells $\left(\mathrm{T}_{\text {con }}\right.$ ). Naive $\mathrm{T}$ cells do not express $\mathrm{CD} 44$ (top-left gate), whereas central memory T cells upregulate CD44 (top-right gate), and effector memory T cells downregulate CD62L but maintain CD44 expression (bottom-right gate). (c, middle) Quantification for the numbers of $\mathrm{T}_{\text {con }}$ cells that are naive or memory cells in the spleens of wild-type and $A 1^{-1-}$ mice demonstrates a significant decrease in the effector and central memory populations $\left(P<0.05\right.$, Mann-Whitney U-test). (c, bottom) The same activation profile can be applied to $C D 4^{+}$FOXP3 ${ }^{+}$regulatory $T$ cells $\left(T_{\text {reg }}\right)$. Quantification of these populations shows a significant decrease in the effector memory $T_{\text {reg }}$ population $\left(P<0.05\right.$, Mann-Whitney $U$-test). (d) $C D 4^{+} T$ cells isolated from the lymph nodes of wild-type (solid lines) and $A 1^{-/-}$(dotted lines) mice were activated in vitro with anti-CD3 antibodies alone (circles), or in combination with anti-CD28 antibodies (squares) or IL-2 (triangles). Data represent the mean \pm S.D. based on three mice for each genotype, with each treatment performed in triplicate 
a

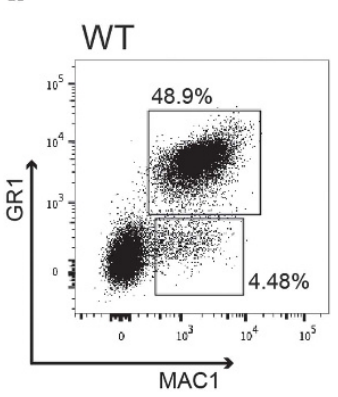

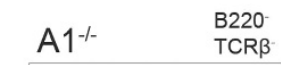
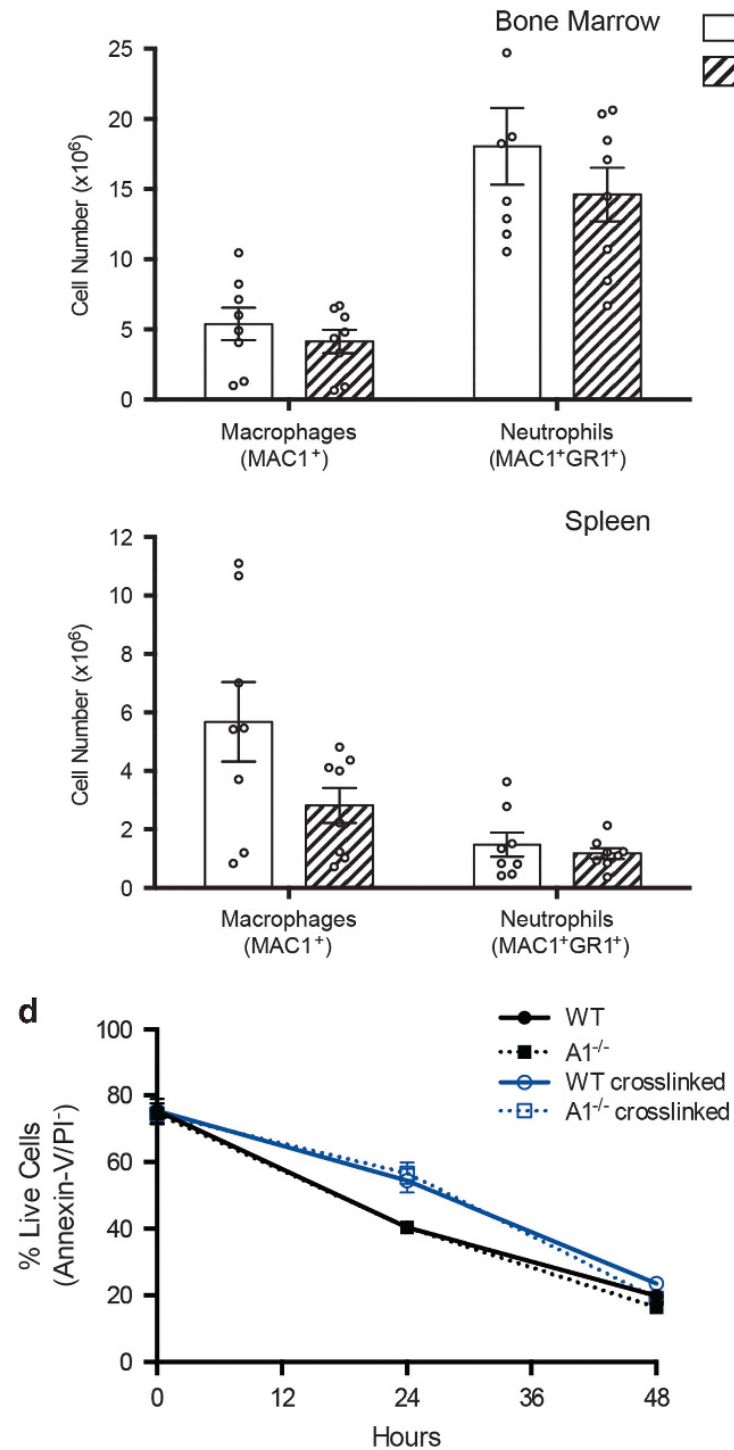

b

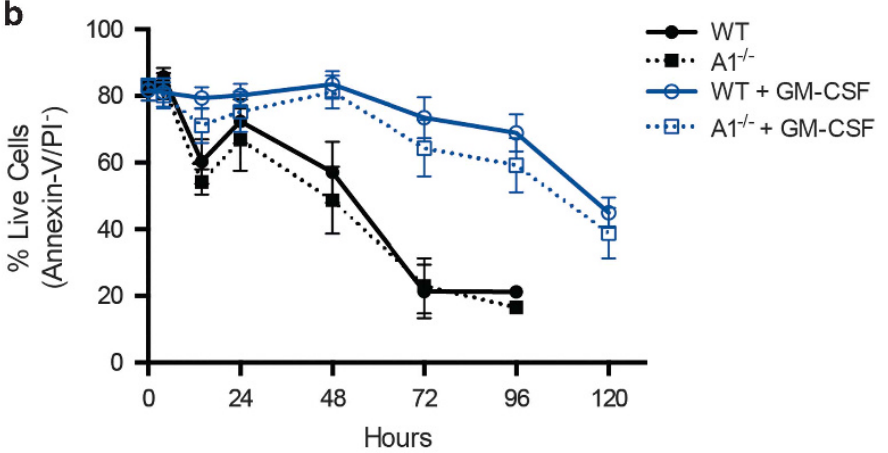

C
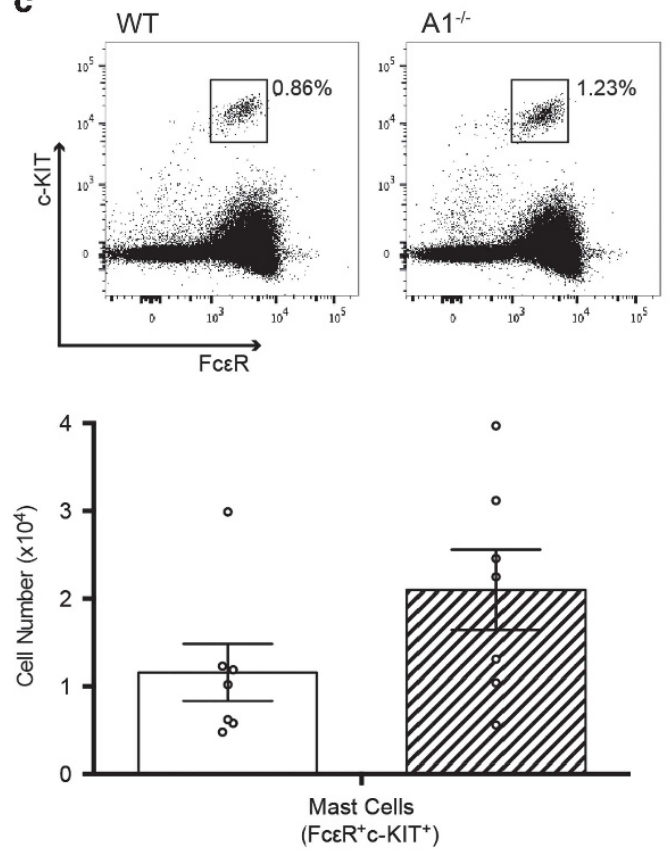

Figure 5 Numbers and survival rates of A1-deficient neutrophils and mast cells in vivo and in vitro are normal. (a, top) Representative FACS plots of bone marrow MAC1 ${ }^{+}$ macrophages and $\mathrm{MAC} 1^{+} \mathrm{GR} 1^{+}$neutrophils, gated on $\mathrm{B} 220^{-} \mathrm{TCR} \beta^{-}$cells. (a, middle and bottom) Total number of macrophages and neutrophils in the bone marrow and spleens of wild-type and $A 1^{-/-}$mice. (b) GR1 ${ }^{\text {hi }}$ neutrophils were sorted from the bone marrow of wild-type and $A 1^{-/-}$mice and stimulated with GM-CSF or kept in simple medium alone to observe spontaneous apoptosis. Cell survival was followed by FACS analysis after staining with Annexin-V and PI. Data are representative of six mice for each genotype, with each treatment in duplicate. (c, top) Representative FACS plots of mast cells $\left(\mathrm{Fc} \varepsilon \mathrm{R}^{+} \mathrm{c}-\mathrm{KIT}^{+}\right)$in the peritoneal cavity of wild-type and $A 1^{-/-}$mice. (c, bottom) The numbers of mast cells in the peritoneum were quantified. (d) Mast cells were derived from wild-type and $A 1^{-/-}$mice by culturing bone marrow cells in the presence of stem cell factor (SCF) and IL-3. After 3 weeks of culture, mast cell survival was assessed after cytokine withdrawal with or without Fc $R$ crosslinking with IgE. Data are representative of three independent mast cell lines derived from individual mice per genotype, with treatments measured in triplicate 
state in the bone marrow and spleen, there were no differences in either the total numbers or proportions of neutrophils or macrophages (Figure $5 \mathrm{a}$ and Supplementary Figure S5a). Moreover, the numbers of other granulocytic cell types (e.g., eosinophils, monocytes) were all normal in the blood of A1-deficient mice (Supplementary Figure S5b). To examine neutrophil apoptosis in culture, neutrophils were FACS-sorted from $A 1^{-/-}$and wild-type mice and then a
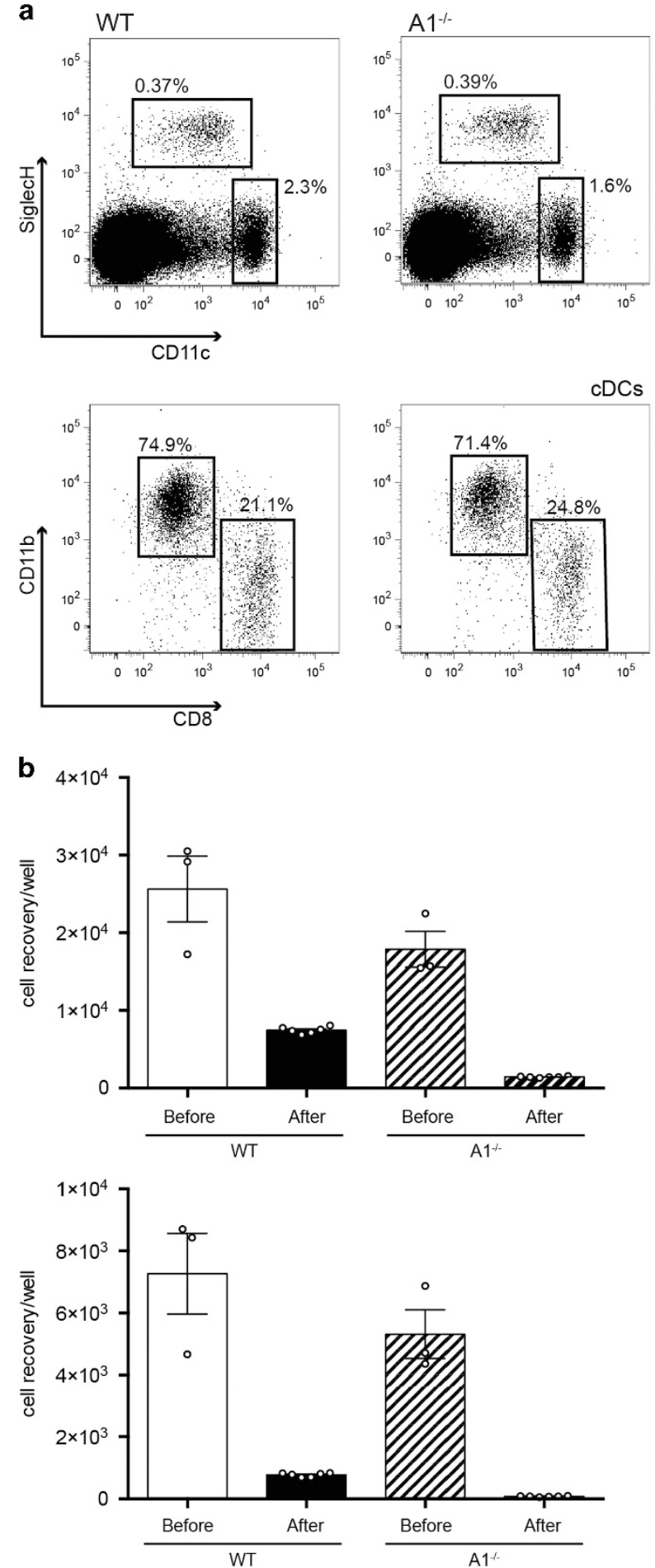
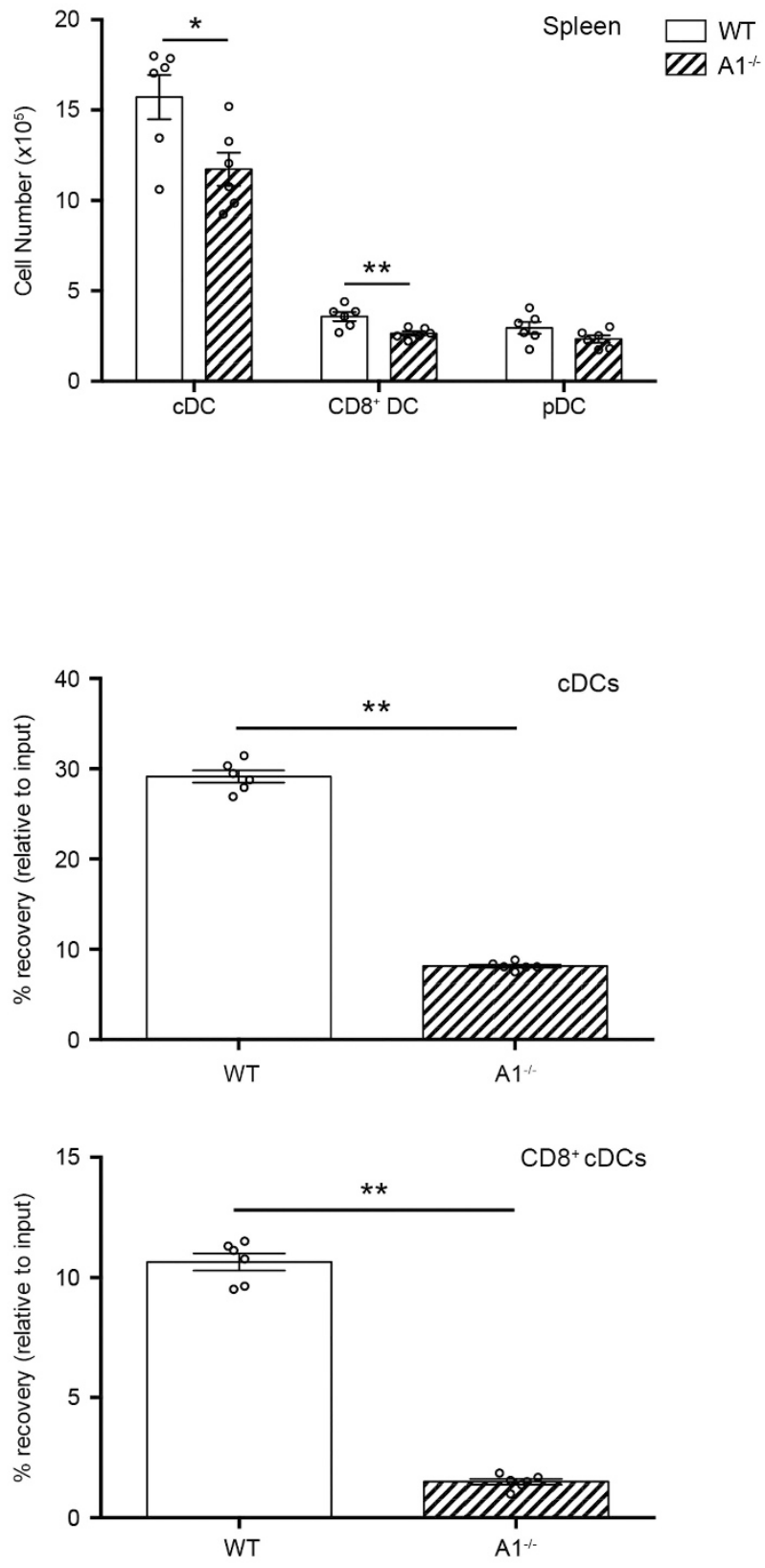

Figure 6 A1-deficient conventional dendritic cells are reduced in vivo and show poorer survival under in vitro culture conditions. (a, left) Representative FACS plots of

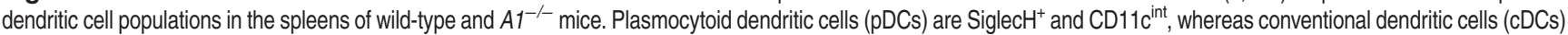
are $C D 11 c^{\text {hi }} . C D C s$ can be further subdivided into $C D 11 b^{+}$and $C D 8^{+} D C s$. (a, right) The numbers of cells for each splenic DC population were quantified. Significance determined by Mann-Whitney U-test $\left({ }^{*} P<0.05,{ }^{* *} P<0.01\right.$ ). (b) Survival of $\mathrm{CDCs}$ (above) and CD8 ${ }^{+} \mathrm{CDCs}$ in culture after $24 \mathrm{~h}$ in culture, as shown by cell recovery (left) and percentage recovery of cell input (right). Significance determined by Mann-Whitney U-test $\left({ }^{*} P<0.05,{ }^{* *} P<0.01\right)$ 
stimulated with GM-CSF or kept in simple medium. Regardless of the treatment applied, there was no significant difference in the survival between wild-type and A1-deficient granulocytes (Figure 5b).

Mast cells are another myeloid cell type that were found to be affected by both A1-a deletion and shRNA-mediated knockdown of $A 1$ in mice. ${ }^{29,31}$ Therefore, we investigated mast cell numbers in the peritoneal cavity. Again, there were no differences in the numbers of mast cells between the A1deficient and wild-type mice (Figure $5 \mathrm{c}$ ). Mast cells were grown in vitro by culturing bone marrow progenitors in the presence of stem cell factor (SCF) and IL-3. The $A 1^{-1-}$ progenitors were able to differentiate normally into mast cells, as shown by expression of c-KIT (the receptor for SCF) and FceR after 3 weeks (Supplementary Figure S5c). Survival assays were performed with these differentiated mast cells after cytokine withdrawal or concomitant stimulation with $\mathrm{Fc \varepsilon R}$ crosslinking (Figure $5 \mathrm{~d}$ ), the calcium ionophore ionomycin, LPS or IL-33 (Supplementary Figure S5d). No difference in survival was observed between A1-deficient and wild-type mast cells under any of these conditions.

High A1 protein expression levels were recently noted in cDCs. ${ }^{33}$ Furthermore, studies using the shRNA knockdown of A1 in mice revealed a marked reduction in cDCs and a compensatory increase in the proportions of plasmacytoid DCs (pDCs). We have been able to recapitulate these results in the $A 1^{-1-}$ mice, in which we also observed a small but significant decrease in both the $\mathrm{CD}_{11 \mathrm{~b}^{+}}$and $\mathrm{CD}^{+} \mathrm{CDC}$ populations in the spleen (Figure $6 \mathrm{a}$ ). There was also a trend towards a reduction in the migratory DC subsets in the lymph nodes, though this was not statistically significant (Supplementary Figure S6). A role for A1 in the survival of cDCs was substantiated by in vitro cell survival assays. Loss of A1 significantly reduced the numbers of live $C D 11 b^{+}$as well as $\mathrm{CD}^{+} \mathrm{cDCs}$ after $24 \mathrm{~h}$ in culture compared with their wild-type counterparts. When calculated as the percentage of cells recovered compared with the initial input, there was an approximately threefold decrease in the survival of $A 1^{-1-}$ cDCs (Figure 6b).

Collectively, these results reveal that $A 1$ has an indispensable role in the survival of $\mathrm{cDCs}$, but either plays no role or has a role overlapping with that of other pro-survival BCL-2 family members in other myeloid cell populations.

\section{Discussion}

The BCL-2 family member A1 has been significantly more challenging to study than its pro-survival relatives, $B C L-2$, $B C L-X L, B C L-W$ and $M C L-1$. This is because of the quadruplication of the $A 1$ gene in mice that makes generating a complete knockout mouse only possible by multiple sequential rounds of gene targeting. This was achieved, and here we describe the characterisation of mice that are completely deficient for all A1 proteins.

The lack of an overt phenotype was somewhat unexpected given the previous reports of prominent $A 1$ expression in $B$ and $T$ lymphocytes, neutrophils, mast cells and dendritic cells. When examining the steady-state haematopoietic cell subset composition of the $A 1^{-/}$mice by flow cytometry, we observed relatively small, although significant, decreases in the numbers of TCR $\gamma \delta \mathrm{T}$ cells, $\mathrm{T}_{\text {reg }}$ cells, $\mathrm{CD}^{+}$memory $\mathrm{T}$ cells and $\mathrm{cDCs}$. For the cDCs, we also found a clear dependence on $A 1$ for survival in culture. This suggests that $A 1$ may be an important factor for $\mathrm{CDC}$ survival under conditions of stress. However, this remains to be demonstrated in vivo.

It was surprising to see no differences in ex vivo cell survival assays for the other leukocyte subsets, given that $A 1$ is upregulated in response to several stimuli that we had tested in these assays. The reduction in antigen-experienced CD4 ${ }^{+}$ memory $T$ cells in the spleen appeared to be in accordance with the A1 upregulation that occurs upon TCR stimulation. However, in vitro assays using mitogenic antibodies against CD3 and CD28 or IL-2 did not reveal any survival defects. Given that this was an in vitro test, it is possible that these signals are stronger than would be physiologically relevant, and may overwhelm the normal processes that control cell survival. This nonphysiological response may induce survival programmes that are not reliant on A1. Alternatively, the prosurvival activity of $B C L-X L$, which is also substantially upregulated upon TCR stimulation, ${ }^{43}$ may fulfil the survival needs of the activated T cells. The in vivo T cell stimulation has been examined using models of influenza and chronic LCMV infection, but no abnormalities were seen in $A 1^{-/}$mice. ${ }^{44}$ Furthermore, upon immunisation with NP-KLH, $A 1^{-/-}$mice failed to reveal any $B$ cell activation defects in vivo. ${ }^{44}$

It has been reported that in mice lacking the $\mathrm{A} 1-\mathrm{a}$ isoform, the inflammatory response to infection with Toxoplasma gondii was less severe compared with wild-type controls in terms of overall peritoneal leukocyte cellularity, but the proportions of granulocytes recruited to the peritoneal cavity were comparable. ${ }^{45}$ This suggests that loss of A1 may impair the survival of certain cell types of the immune system to a minor extent, but not enough to preclude A1-deficient mice to respond adequately to infectious challenges. It remains, however, possible that the type of immune challenge that relies heavily on $\mathrm{A} 1$ has not yet been experimentally tested. Thus, there is room for exploration of a host of parasitic and bacterial infection models. In fact, A1 was recently implicated in Mycobacterium tuberculosis infection, as $A 1$ mRNA was found to be substantially upregulated in infected macrophages, suggesting that A1 may promote the survival of such infected cells. ${ }^{46}$ Interestingly, a recent study showed that BCL$\mathrm{XL}$-specific $\mathrm{BH} 3$ mimetics potently kill Legionella-infected macrophages and thereby protect mice from pathology induced by these bacteria. ${ }^{47}$ Should loss of A1 kill Mycobacterium tuberculosis macrophages, it would be of interest to generate $\mathrm{A} 1$-specific $\mathrm{BH} 3$ mimetics to test for treatment of tuberculosis.

Many of the results from our studies of the $A 1^{-/-}$mice are in discordance with previous investigations of the in vivo function of $\mathrm{A} 1$ using $A 1$-a-deficient mice or $A 1$ shRNA knockdown mice. For example, the $A 1$-a knockout mice exhibited defects in neutrophil and mast cell survival in culture. ${ }^{28,29}$ We found no abnormal reduction of either of these myeloid cell populations in our $A 1^{-/-}$mice, and did not observe any significant defect in their survival in culture, both with and without stimulation. Although we have not performed in vivo assays in which neutrophils or mast cells are challenged, for example by microbes or allergens, our data do not suggest any impairment in this regard. Differences in genetic background between the 
A1-a-deficient and our $A 1^{-/}$mice may explain the disparities, as previous reports have described an impact of genetic background on cell death assays. ${ }^{48}$

Our analyses of mice lacking all functional A1 isoforms reveal that there is functional redundancy with the other prosurvival members of the BCL-2 family. We found no evidence for dramatic compensatory effects such as upregulation of MCL-1, BCL-XL or BCL-2 or downregulation of BIM in the cells of $A 1^{-1-}$ mice that we have examined. However, one could argue that the germline deletion of all $\mathrm{A} 1$ isoforms removes any pressure for upregulation of the other pro-survival proteins to perform A1 function, because A1 was never present. Our model is limited in that it is not possible to conditionally delete all $\mathrm{A} 1$ isoforms, as the conditional knockout allele lacks $B c / 2 a 1 a$ and $B c / 2 a 1 d$, with only Bcl2a $1 b$ flanked by loxP sites. Analyses have been performed of acute deletion of $A 1-b$, through the use of a RosaCreERT2; $A 1^{f l / f l}$ tamoxifen-inducible Cre model, but these tests similarly did not show any differences in cell survival compared with control animals (data not shown).

Arguably, the doxycycline-inducible $A 1$ shRNA transgenic knockdown model could address this question of the relative impact of germline versus acute A1 gene deletion. However, there were many discrepancies between the shRNA-mediated knockdown of $A 1$ and our constitutive $A 1$ knockout mice that make it difficult to compare the two models. In the constitutive knockdown mice ${ }^{30,31}$ significant differences were observed in double-negative thymocytes, mature B cells and granulocytes, none of which could be recapitulated in the $A 1$-deficient mice. These inconsistencies are likely to have arisen from the fact that there is much less control of decreasing $A 1$ expression when using transgenic expression of the $A 1$ shRNA compared with a complete $A 1$ knockout. Furthermore, off-target effects, such as undue stress to cells because of expression of the $A 1$ shRNA transgene, may occur. These limitations are evident when comparing the original $A 1$ shRNA knockdown mice ${ }^{30}$ with the inducible $A 1$ shRNA model, ${ }^{32}$ as the aforementioned defects in the former were not reflected in the latter. On balance, given the genetic complications from having four copies of the $A 1$ gene in mice, we believe that our current mouse model is the best to study $\mathrm{A} 1$ function in vivo.

The finding that complete loss of $A 1$ has only minor impact on the whole animal may have interesting implications for the development of drugs that inhibit this pro-survival protein, as they would be predicted to have only minor toxicity. $\mathrm{BH} 3$ mimetic compounds, akin to the recently FDA approved BCL-2-specific inhibitor Venetoclax (ABT-199), ${ }^{49}$ or the newly described MCL-1 inhibitor S63845 soon entering first clinical trials, ${ }^{50}$ but inhibiting specifically $A 1$, may be useful for the treatment of certain types of lymphoma, melanoma and stomach cancer, as these cancers were found to express abnormally high levels of $A 1 .^{21}$

In conclusion, our studies reveal that A1 is not a vital prosurvival protein in normal physiology. Our gene-targeted mice will be useful (and will be made freely available) to examine the role of A1 in cancer development, infectious diseases and other conditions of stress.
Materials and Methods

Generation of $\mathrm{A1}^{-/-}$mice. The $A 1^{f / /+}$ mice were generated by Taconic Biosciences $\mathrm{GmbH}$ (Cologne, Germany). The targeting constructs (Figure 1a) were transfected into the Taconic Biosciences C57BL/6NTac ES cell line, sequentially in the order of A1-a (Bcl2a1a), A1-d (Bcl2a1d) and A1-b (Bcl2a1b). Each targeting construct contained a unique antibiotic resistance cassette for positive selection, and thymidine kinase cassette for negative selection. For Bcl2a1a, both exons as well as a $\sim 1.5 \mathrm{~kb}$ region upstream (promoter region) were targeted $(\sim 7 \mathrm{~kb}$ region in total). For both $B c l 2 a 1 d$ and $B c l 2 a 1 b$, only their exons 1 and the promoter regions (1.5 kb upstream) were targeted ( $2.5 \mathrm{~kb}$ regions). Bcl2a1a and Bcl2a1d were targeted for deletion, whereas the $B c / 2 a 1 b$ targeting construct replaced the wild-type allele with the promoter and exon 1 of Bcl2a1b flanked by loxP sites (Supplementary Figure S1a). For diagnostic in vitro deletion tests, that is, to verify that targeting of $A 1$ isoforms had occurred on the same chromosome, lox5171 and attB/P sites were also inserted and confirmed by Southern blotting (Supplementary Figure S1b).

Successfully targeted ES cell clones were selected and microinjected into BALB/c blastocysts isolated at dpc 3.5. Recovered blastocysts were transferred into pseudopregnant mice and resultant chimaerism of offspring was determined by coat colour contribution of ES cell-derived cells. Highly chimaeric mice were bred to the C57BL/6 strain, with mating partners from the C57BL/6-Tg(CAG-Flpe)2 Arte transgenic mice carrying the FLP recombinase (FLPe). The action of the FLP recombinase removed the antibiotic resistance cassettes, giving the $B c / 2 a 1 d$ and $\mathrm{Bcl} 2 \mathrm{a} 1 \mathrm{a}$ constitutive $\mathrm{KO} / \mathrm{Bcl} 2 \mathrm{a} 1 \mathrm{~b}$ conditional $\mathrm{KO}$ allele. Presence of the $\mathrm{FLPe}$ transgene and loss of antibiotic resistance cassettes were confirmed by PCR (see supplementary Table S2 for details of PCR primers).

Mice bearing this allele were transferred to the Walter and Eliza Hall Institute (WEHI) animal facility, where they were crossed with C57BL/6 deleter CMV-Cre mice $^{51}$ to breed out the FLPe transgene and to cause recombination at the loxP sites flanking $A 1-b$ to produce the constitutive knockout allele $\left(A 1^{+/-}\right.$mice). $A 1^{+/-}$, $\mathrm{Cre}{ }^{T /+}$ mice were crossed with $A 1^{+/-}$mice in order to generate $A 1^{-/-}$mice. Two independent colonies of $A 1^{-/}$were generated from two independent $A 1$ genetargeted ES cells. All animal experiments were performed in accordance with ethics criteria as set out by the WEHI Animal Ethics Committee.

Genotyping was performed by PCR to confirm loss of the FLPe transgene, presence or absence of the CMV-Cre transgene, deletion of Bcl2a1a/Bcl2a1d, the floxed $B c / 2 a 1 b$ allele and, later, the loss of the Bcl2a1b allele (Supplementary Figure S1c and Supplementary Table S2).

Haematopoietic analysis. The haematopoietic organs - thymus, spleen, bone marrow (both tibias and femurs) and lymph nodes (axial, inguinal, brachial and one mesenteric) - were harvested from 6-12-week-old mice and then used for FACS analysis, western blotting or in vitro experiments. Peripheral blood was collected by eye bleed, and analysed using the ADVIA automated haematology system (Bayer, Tarrytown, NY, USA).

Flow cytometry. Monoclonal antibodies used were either purchased from eBioscience (San Diego, CA, USA), Biolegend (San Diego, CA, USA) or made inhouse at the Walter and Eliza Hall Antibody Facility. Their specificities are: Ter119 (Ter119), MAC1 (M1/70), B220 (14.8 or RA3-6B2), NK1.1 (PK136), CD3 (145-2C11), CD4 (GK1.5, H129 or YTA3.2.1), CD8 (53-6.7 or YTS169), CD25 (PC61), TCR $\beta$ (H57-597), $\gamma \delta \mathrm{TCR}$ (GL3), Gr1 (RB6-8C5), CD5 (53-7.3), IgM (RMM-1 or 5.1), CD19 (1D3), CD43 (57), FceR (MAR-1), cKIT(2B8), IgD (11-26C), FOXP3 (FJK-16s), CD62L (MEL-14) and CD44 (IM7 or IM781). Streptavidin conjugates of PE-Cy7 (Biolegend) and Alexafluor-594 (Life Technologies, Waltham, MA, USA) were used for detection of biotin-conjugated antibodies. Dead cells were excluded from analysis by staining with propidium iodide (PI, $5 \mu \mathrm{g} / \mathrm{ml})$. Intracellular staining was performed using the eBioscience intracellular fixation and permeabilisation buffer set. Antibodies used for the intracellular staining of the BCL-2 family members were: BCL-2 (3F11, BD Pharmingen, BD Biosciences, San Jose, CA, USA), BCL-XL (E18, Abcam, Cambridge, UK), MCL-1 (19C4-15, WEHI ${ }^{52}$ ), and BIM (3C5, WEHI).

Stained cells were analysed with LSRII, Fortessa1 or Fortessa X20 analysers, and cell sorting was performed using the Aria high-speed cell sorter (Becton Dickson, Franklin Lakes, NJ, USA). FACS data were analysed with FlowJo software (Treestar, Ashland, OR). Cell numbers of populations were determined using whole organ cell counts that were determined on the CASY counter (Schärfe System $\mathrm{GmbH}$, Reutlingen, Germany).

Western blotting. Cell lysates were prepared from single-cell suspensions of FACS-sorted spleen and thymus. Lysates were prepared in Onyx buffer 
(20 mM Tris-HCl pH 7.4, $135 \mathrm{mM} \mathrm{NaCl}, 1.5 \mathrm{mM} \mathrm{MgCl}, 1$ mM EGTA, 1\% (v/v) Triton $\mathrm{X}-100,10 \%(\mathrm{~V} / \mathrm{V})$ glycerol) with added protease inhibitor cocktail (Roche, Basel, Switzerland). Protein concentration was determined by Bradford assay using the Protein Assay Dye Reagent Concentrate (Bio-Rad, Hercules, CA, USA). Proteins were size fractionated by gel electrophoresis on NuPAGE $10 \%$ Bis-Tris $1.5 \mathrm{~mm}$ gels (Life Technologies) in MES buffer and then transferred onto nitrocellulose membranes (Life Technologies) using the iBlot membrane transfer system. The following primary antibodies were diluted in $5 \%$ skim milk in PBS-T buffer to probe for the pro-survival $\mathrm{BCL}-2$ family proteins: monoclonal rat anti-mouse $\mathrm{A} 1$ (clone $6 \mathrm{D6}$, WEHI antibody facility), ${ }^{34}$ monoclonal rat anti-mouse MCL-1 (clone 19C4-15, WEHI antibody facility), ${ }^{52}$ polyclonal rabbit anti-mouse BCL-XL (BD Biosciences 610212) and monoclonal mouse anti-BCL-2 (clone 7, BD Biosciences). Probing for HSP70 (antibody clone N6, gift from Dr. R Andersson, Peter MacCallum Cancer Research Centre, Melbourne, VIC, Australia) was used as a protein loading control. Secondary anti-rat/mouse/rabbit IgG antibodies conjugated to HRP (Southern BioTech, Birmingham, AL, USA) were applied, followed by Luminata Forte Western HRP substrate (Millipore, Billerica, MA, USA) for band visualisation. Membranes were imaged using the ChemiDoc XRS+ machine with ImageLab software (Bio-Rad).

B cell stimulation. B cell blasts were generated by stimulation of splenocytes cultured in DME medium (Thermo Fisher Scientific, Waltham, MA, USA) containing 10\% (v/v) FCS (Sigma-Aldrich, St Louis, MO, USA), $40 \mathrm{mM}$ sodium bicarbonate, $1 \mathrm{mM}$ HEPES, $100 \mathrm{U} / \mathrm{ml}$ penicillin/streptomycin, $0.0135 \mathrm{mM}$ folic acid, $0.24 \mathrm{mM}$ L-asparagine monohydrate, $0.55 \mathrm{mM}$ L-arginine monohydrochloride, $50 \mu \mathrm{M}$ $\beta$-mercaptoethanol, and $100 \mu \mathrm{M}$ asparagine (hereafter called FMA medium) with $2 \mu \mathrm{g} / \mathrm{ml}$ anti-IgM F(ab')2 fragments (Jackson ImmunoResearch, West Grove, PA USA) in the presence of IL-4 and IL-5 or with cytokines alone as a control. Cells were seeded at $1 \times 10^{5}$ cells/well and cultured in 96 -well plates, or $3 \times 10^{6}$ cells/well in 6-well plates for intracellular FACS staining. Cell survival was analysed by staining with Annexin-V conjugated to FITC or Alexafluor-647 and PI $(5 \mu \mathrm{g} / \mathrm{ml})$ followed by flow cytometric analysis.

Thymocyte death assays. Unsorted thymocytes were placed in culture in FMA medium alone or with addition of ABT-737 (inhibitor of BCL-2, BCL-XL and $\mathrm{BCL}-\mathrm{W} ; 0.5 \mu \mathrm{M})$, dexamethasone $(0.5 \mathrm{ng} / \mathrm{ml})$, etoposide $(0.5 \mu \mathrm{g} / \mathrm{ml})$, ionomycin $(0.1 \mu \mathrm{g} / \mathrm{ml})$ or PMA $0.5 \mathrm{ng} / \mathrm{ml})$. Cells were seeded at $1 \times 10^{5}$ cells/well and cultured in 96-well plates. Cell survival was analysed using flow cytometry after staining with Annexin-V conjugated to FITC or Alexafluor-A647 and PI $(5 \mu \mathrm{g} / \mathrm{ml})$.

T cell stimulation. T cells were cultured in RPMI- 1640 medium supplemented with $10 \%$ (v/v) FCS, $10 \mathrm{mM}$ Hepes, $100 \mathrm{U} / \mathrm{ml}$ penicillin, $100 \mu \mathrm{g} / \mathrm{ml}$ streptomycin, $2 \mathrm{mM}$ GlutaMAX, $0.1 \mathrm{mM}$ non-essential amino acids, $1 \mathrm{mM}$ sodium pyruvate (all from Invitrogen, Carlsbad, CA, USA) and $50 \mu \mathrm{M} \beta$-mercaptoethanol (Sigma). $\mathrm{CD}^{+} \mathrm{T}$ cells were isolated from mouse lymph nodes (inguinal, axillary, brachial and superficial cervical) by negative selection using the EasySep Mouse $\mathrm{CD} 4^{+} \mathrm{T}$ cell Isolation kit (StemCell Technologies, Vancouver, BC, Canada). Purity was typically $>95 \%$. CD4 ${ }^{+}$T cells were stimulated with plate-bound anti-CD3 antibody $(10 \mu \mathrm{g} / \mathrm{ml}$, clone 145-2C11, WEHI monoclonal antibody facility), with $2 \mu \mathrm{g} / \mathrm{ml}$ anti-CD28 antibody (clone 37.51, WEHI monoclonal antibody facility) or $10 \mathrm{U} / \mathrm{ml}$ human IL-2 (h-IL-2) (Peprotech, Rocky Hill, NJ, USA) added to the cultures as indicated. All T cell cultures contained $25 \mu \mathrm{g} / \mathrm{ml}$ anti-mouse IL-2 antibody (clone S4B6, WEHI monoclonal antibody facility) that blocks the activity of mouse IL-2 in vitro but does not block human IL-2. ${ }^{53}$ To track cell division, cells were labelled with $5 \mu \mathrm{M}$ CellTrace Violet (CTV) (Invitrogen) according to the manufacturer's instructions. Cells were seeded at $1 \times 10^{4}$ cells/well and cultured in 96-well plates. A known number of beads (Rainbow calibration particles BD Biosciences) were added to samples immediately before analysis and the ratio of beads to live cells was used to calculate the absolute cell number in each sample. PI was used for dead cell exclusion at $0.2 \mu \mathrm{M}$. The mean division number (MDN) is calculated using the precursor cohort method as described previously. ${ }^{54}$ For intracellular FACS staining, $3 \times 10^{6}$ cells/well were seeded in 6 -well plates coated with anti-CD3 antibody as above.

Neutrophil survival assays in culture. Bone marrow was collected from the tibias and femurs of mice, and then FACS-sorted for $\mathrm{Gr}^{\text {hi }}{ }^{\text {cells. Cells were }}$ plated at $3 \times 10^{4}$ cells/well in 96-well plates in either medium alone (RPMI-1640, $10 \%$ (v/v) FCS) or medium containing $10 \mathrm{ng} / \mathrm{ml}$ murine recombinant GM-CSF (kindly provided by Dr. Jian-Guo Zhang of WEHI). Cell survival was determined by flow cytometry after staining with Annexin-V-FITC and PI.
Generation of bone marrow-derived mast cells and stimulation in vitro. Bone marrow was collected from the tibias and femurs of mice and placed in culture in mast cell medium (DMEM, 10\% FCS, 2 mM glutamine, $0.1 \mathrm{mM}$ non-essential amino acids, $1 \mathrm{mM}$ pyruvate and $50 \mu \mathrm{M} \beta$-mercaptoethanol) supplemented with fresh mouse SCF $(12.5 \mathrm{ng} / \mathrm{ml}$, recombinant protein produced in-house and kindly provided by Dr. Jian-Guo Zhang of WEHI) and IL-3 (supernatant from X63/0-IL-3 cells ${ }^{55}$ ) weekly. After 3 weeks of culture, cells were assessed by flow cytometry for mast cell differentiation by staining for $\mathrm{F} c \varepsilon \mathrm{R}$ and $\mathrm{c}-\mathrm{KIT}$. Subsequent experiments using these mast cells were all performed within 6 weeks. For FceR crosslinking survival assays, mast cells were incubated overnight with lgE specific for TNP (supernatant from TiB142 cells kindly provided by Dr. Graham Mackay, University of Melbourne, Parkville, Australia) before washing with PBS to remove cytokines and stimulated with TNP-BSA (100 ng/ml; Biosearch Technologies, Novato, CA, USA). As a control, cells were not incubated with lgE, but subjected to the same incubation times and wash steps. For ionomycin, LPS and IL-33 treatment survival assays, cells were washed to remove cytokines and then treated with $1 \mu \mathrm{g} / \mathrm{ml}$ ionomycin, $5 \mu \mathrm{g} / \mathrm{ml}$ ultrapure LPS (E. coli 0111:B4 strain-TLR4 ligand, InvivoGen, San Diego, CA, USA), $10 \mathrm{ng} / \mathrm{ml} \mathrm{IL-33} \mathrm{(produced} \mathrm{in-house} \mathrm{and} \mathrm{kindly} \mathrm{provided} \mathrm{by} \mathrm{Dr.}$ Ajithkumar Vasanthakumar of WEHI) or medium alone (no cytokines added). Cells were plated at $1-6 \times 10^{4}$ cells/well in 96 -well plates. Cell survival was analysed by flow cytometry after staining with Annexin-V and PI.

Dendritic cell analysis. Spleen and pooled subcutaneous lymph node (axial, brachial, inguinal and cervical) suspensions were prepared by digestion in Collagenase/Dnase-1 as previously described. ${ }^{56}$ Red blood cells in spleen were lysed in $0.156 \mathrm{M} \mathrm{NH}_{4} \mathrm{Cl}$ unless further enrichment was required. Anti-CD11c, CD11b, CD8, Siglec-H, CD326 and CD103 (BD Biosciences) were used to identify dendritic cell subsets by flow cytometry, with absolute cell numbers determined by the addition of fluorochrome-conjugated calibration beads (BD Biosciences) added directly to samples. Data were collected using a FACSverse (BD Biosciences) and analysed using FlowJo software (Treestar).

For cell culture assays, splenocytes were enriched for DCs using a Nycodenz density gradient as previously described (Vremec et al., 2000). Enriched cells were seeded at $2 \times 10^{5}$ cells per well in $200 \mu \mathrm{l}$ RPMl supplemented with $10 \%$ FCS in a flat bottom plate, with cells harvested immediately (uncultured) or after overnight culture in $10 \% \mathrm{CO}_{2}$ at $37^{\circ} \mathrm{C}$. Upon harvesting, cells were stained for cell surface markers, and cell survival and live cell numbers were determined by flow cytometry after adding fluorochrome-conjugated calibration beads (BD Biosciences) and PI.

Statistical analyses. All statistical analyses were performed using Prism software (GraphPad, La Jolla, CA, USA), with the Mann-Whitney U-test used to determine statistical significance defined by a $P$-value of $<0.05$. Specifically, ${ }^{*} P<0.05$, ${ }^{* *} P<0.01$ and ${ }^{* * \star} P<0.001$. All data are presented as mean \pm S.E.M., unless otherwise indicated.

\section{Conflict of Interest}

The authors declare no conflict of interest.

Acknowledgements. We thank all members of the Herold laboratory for their support and advice. G Siciliano, H Johnson and their team for animal husbandry; S Monard and his team for help with flow cytometry unit. This work was supported by a Leukemia Foundation National Research Program PhD Scholarship (to RLS), National Health and Medical Research Council, Australia (program grant 1016701 and fellowship 1020363 to AS) and project grant APP1049720 (to MJH). This work was made possible through Victorian State Government Operational Infrastructure Support and Australian Government National Health and Medical Research Council Independent Research Institutes Infrastructure Support Scheme and by grants from the Austrian Science Fund (FWF), Grant I1298 (FOR-2036) and W1101 (MCBO). ST is supported by a Doc-fellowship from the Austrian Academy of Science (ÖAW).

\section{Author contributions}

RLS performed experiments, analysed data, wrote paper and prepared figures; ST, EMC, YZ, CET, DHG, AML and SH performed experiments, analysed data and prepared figures; $\mathrm{MJH}$ conceived and planned study, analysed data and wrote paper; $\mathrm{AV}$ and AS planned study design, analysed data and wrote the paper.

1. Strasser A, O'Connor L, Dixit VM. Apoptosis signaling. Annu Rev Biochem 2000; 69: 217-245.

2. Kamada S, Shimono A, Shinto Y, Tsujimura T, Takahashi T, Noda T et al. bcl-2 deficiency in mice leads to pleiotropic abnormalities: accelerated lymphoid cell death in thymus and 
spleen, polycystic kidney, hair hypopigmentation, and distorted small intestine. Cancer Res 1995; 55: 354-359.

3. Nakayama K, Nakayama K, Negishi I, Kuida K, Shinkai Y, Louie MC et al. Disappearance of the lymphoid system in Bcl-2 homozygous mutant chimeric mice. Science 1993; 261: 1584-1588.

4. Veis DJ, Sorenson CM, Shutter JR, Korsmeyer SJ. Bcl-2-deficient mice demonstrate fulminant lymphoid apoptosis, polycystic kidneys, and hypopigmented hair. Cell 1993; 75: 229-240.

5. Motoyama N, Wang F, Roth KA, Sawa H, Nakayama K, Nakayama K et al. Massive cell death of immature hematopoietic cells and neurons in Bcl-x-deficient mice. Science 1995; 267: 1506-1510.

6. Mason KD, Carpinelli MR, Fletcher Jl, Collinge JE, Hilton AA, Ellis S et al. Programmed anuclear cell death delimits platelet life span. Cell 2007; 128: 1173-1186.

7. Wagner KU, Claudio E, Rucker EB 3rd, Riedlinger G, Broussard C, Schwartzberg PL et al. Conditional deletion of the $\mathrm{Bcl}-\mathrm{x}$ gene from erythroid cells results in hemolytic anemia and profound splenomegaly. Development 2000; 127: 4949-4958.

8. Rinkenberger JL, Horning S, Klocke B, Roth K, Korsmeyer SJ. Mcl-1 deficiency results in peri-implantation embryonic lethality. Genes Dev 2000; 14: 23-27.

9. Arbour N, Vanderluit JL, Le Grand JN, Jahani-Asl A, Ruzhynsky VA, Cheung EC et al. Mcl-1 is a key regulator of apoptosis during CNS development and after DNA damage. J Neurosci 2008; 28: 6068-6078.

10. Opferman JT, Letai A, Beard C, Sorcinelli MD, Ong CC, Korsmeyer SJ. Development and maintenance of B and T lymphocytes requires antiapoptotic MCL-1. Nature 2003; 426: 671-676.

11. Opferman JT, Iwasaki H, Ong CC, Suh H, Mizuno S, Akashi K et al. Obligate role of anti-apoptotic MCL-1 in the survival of hematopoietic stem cells. Science 2005; 307: $1101-1104$

12. Thomas RL, Roberts DJ, Kubli DA, Lee Y, Quinsay MN, Owens JB et al. Loss of MCL-1 leads to impaired autophagy and rapid development of heart failure. Genes Dev 2013; 27: 1365-1377.

13. Wang X, Bathina M, Lynch J, Koss B, Calabrese C, Frase S et al. Deletion of MCL-1 causes lethal cardiac failure and mitochondrial dysfunction. Genes Dev 2013; 27: 1351-1364.

14. Peperzak V, Vikstrom I, Walker J, Glaser SP, LePage M, Coquery CM et al. Mcl-1 is essential for the survival of plasma cells. Nat Immunol 2013; 14: 290-297.

15. Vikstrom I, Carotta S, Luthje K, Peperzak V, Jost PJ, Glaser S et al. Mcl-1 is essential for germinal center formation and B cell memory. Science 2010; 330: 1095-1099.

16. Print CG, Loveland KL, Gibson L, Meehan T, Stylianou A, Wreford N et al. Apoptosis regulator bcl-w is essential for spermatogenesis but appears otherwise redundant. Proc Natl Acad Sci USA 1998; 95: 12424-12431.

17. Ross AJ, Waymire KG, Moss JE, Parlow AF, Skinner MK, Russell LD et al. Testicular degeneration in Bclw-deficient mice. Nat Genet 1998; 18: 251-256.

18. Lin EY, Orlofsky A, Berger MS, Prystowsky MB. Characterization of A1, a novel hemopoieticspecific early-response gene with sequence similarity to bcl-2. J Immunol 1993; 151: 1979-1988.

19. Choi SS, Park IC, Yun JW, Sung YC, Hong SI, Shin HS. A novel Bcl-2 related gene, Bfl-1, is overexpressed in stomach cancer and preferentially expressed in bone marrow. Oncogene 1995; 11: 1693-1698.

20. Lin EY, Orlofsky A, Wang HG, Reed JC, Prystowsky MB. A1, a Bcl-2 family member, prolongs cell survival and permits myeloid differentiation. Blood 1996; 87: 983-992.

21. Vogler M. BCL2A1: the underdog in the BCL2 family. Cell Death Differ 2012; 19: 67-74.

22. Grumont RJ, Rourke IJ, Gerondakis S. Rel-dependent induction of $A 1$ transcription is required to protect $B$ cells from antigen receptor ligation-induced apoptosis. Genes Dev 1999; 13: 400-411.

23. Wang CY, Guttridge DC, Mayo MW, Baldwin AS Jr. NF-kappaB induces expression of the $\mathrm{Bcl}-2$ homologue $\mathrm{A} 1 / \mathrm{Bfl}-1$ to preferentially suppress chemotherapy-induced apoptosis. $\mathrm{Mol}$ Cell Biol 1999; 19: 5923-5929.

24. Zong WX, Edelstein LC, Chen C, Bash J, Gelinas C. The prosurvival Bcl-2 homolog Bfl-1/A is a direct transcriptional target of NF-kappaB that blocks TNFalpha-induced apoptosis. Genes Dev 1999; 13: 382-387.

25. Duriez PJ, Wong F, Dorovini-Zis K, Shahidi R, Karsan A. A1 functions at the mitochondria to delay endothelial apoptosis in response to tumor necrosis factor. J Biol Chem 2000; 275: 18099-18107.

26. Hatakeyama S, Hamasaki A, Negishi I, Loh DY, Sendo F, Nakayama K et al. Multiple gene duplication and expression of mouse bcl-2-related genes, A1. Int Immunol 1998; 10: 631-637.

27. Ottina $E$, Tischner D, Herold MJ, Villunger A. A1/Bfl-1 in leukocyte development and cell death. Exp Cell Res 2012; 318: 1291-1303.

28. Hamasaki A, Sendo F, Nakayama K, Ishida N, Negishi I, Nakayama K et al. Accelerated neutrophil apoptosis in mice lacking A1-a, a subtype of the bcl-2-related A1 gene. J Exp Med 1998; 188: 1985-1992.

29. Xiang Z, Ahmed AA, Moller C, Nakayama K, Hatakeyama S, Nilsson G. Essential role of the prosurvival bcl-2 homologue A1 in mast cell survival after allergic activation. J Exp Med 2001; 194: 1561-1569.

30. Ottina E, Grespi F, Tischner D, Soratroi C, Geley S, Ploner A et al. Targeting antiapoptotic A1/Bfl- 1 by in vivo RNAi reveals multiple roles in leukocyte development in mice. Blood 2012; 119: $6032-6042$
31. Ottina E, Lyberg K, Sochalska M, Villunger A, Nilsson GP. Knockdown of the antiapoptotic Bcl-2 family member A1/Bfl-1 protects mice from anaphylaxis. J Immunol 2015; 194 1316-1322.

32. Sochalska M, Ottina E, Tuzlak S, Herzog S, Herold M, Villunger A. Conditional knockdown of BCL2A1 reveals rate-limiting roles in BCR-dependent B cell survival. Cell Death Differ 2016; 23: 628-639.

33. Carrington EM, Zhang JG, Sutherland RM, Vikstrom IB, Brady JL, Soo P et al. Prosurvival $\mathrm{Bcl}-2$ family members reveal a distinct apoptotic identity between conventional and plasmacytoid dendritic cells. Proc Natl Acad Sci USA 2015; 112: 4044-4049.

34. Lang MJ, Brennan MS, O'Reilly LA, Ottina E, Czabotar PE, Whitlock E et al. Characterisation of a novel A1-specific monoclonal antibody. Cell Death Dis 2014; 5: e1553.

35. Venigalla RK, McGuire VA, Clarke R, Patterson-Kane JC, Najafov A, Toth $R$ et al. PDK1 regulates VDJ recombination, cell-cycle exit and survival during $B$ cell development. EMBO 2013; 32: 1008-1022

36. Trescol-Biemont MC, Verschelde C, Cottalorda A, Bonnefoy-Berard N. Regulation of A1/Bfl-1 expression in peripheral splenic B cells. Biochimie 2004; 86: 287-294.

37. Wen R, Chen Y, Xue L, Schuman J, Yang S, Morris SW et al. Phospholipase Cgamma2 provides survival signals via $\mathrm{Bcl} 2$ and $\mathrm{A} 1$ in different subpopulations of $\mathrm{B}$ cells. J Biol Chem 2003; 278: 43654-43662.

38. Mandal M, Borowski C, Palomero T, Ferrando AA, Oberdoerffer P, Meng F et al. The BCL2A1 gene as a pre-T cell receptor-induced regulator of thymocyte survival. J Exp Med 2005; 201: 603-614.

39. Verschelde C, Michonneau D, Trescol-Biemont MC, Berberich I, Schimpl A, BonnefoyBerard N. Overexpression of the antiapoptotic protein A1 promotes the survival of double positive thymocytes awaiting positive selection. Cell Death Differ 2006; 13: 1213-1221.

40. Gonzalez J, Orlofsky A, Prystowsky MB. A1 is a growth-permissive antiapoptotic factor mediating postactivation survival in T cells. Blood 2003; 101: 2679-2685.

41. Verschelde C, Walzer T, Galia P, Biemont MC, Quemeneur L, Revillard JP et al. A1/Bfl-1 expression is restricted to TCR engagement in T lymphocytes. Cell Death Differ 2003; 10: 1059-1067.

42. Vier J, Groth M, Sochalska M, Kirschnek $\mathrm{S}$. The anti-apoptotic Bcl-2 family protein A1/Bfl-1 regulates neutrophil survival and homeostasis and is controlled via PI3K and JAK/STAT signaling. Cell Death Dis 2016; 7: e2103.

43. Koenen P, Heinzel S, Carrington EM, Happo L, Alexander WS, Zhang JG et al. Mutually exclusive regulation of $\mathrm{T}$ cell survival by IL-7R and antigen receptor-induced signals. Nat Commun 2013 4: 1735.

44. Tuzlak S, Schenk RL, Vasanthakumar A, Preston SP, Haschka MD, Zotos D et al. The BCL-2 pro-survival protein $\mathrm{A} 1$ is dispensable for $\mathrm{T}$ cell homeostasis on viral infection Cell Death Diff 2016 (in press; doi:10.1038/cdd.2016.155)

45. Orlofsky A, Weiss LM, Kawachi N, Prystowsky MB. Deficiency in the anti-apoptotic protein A1a results in a diminished acute inflammatory response. J Immunol 2002; 168: 1840-1846.

46. Halder P, Kumar R, Jana K, Chakraborty S, Ghosh Z, Kundu M et al. Gene expression profiling of Mycobacterium tuberculosis Lipoarabinomannan-treated macrophages: a role of the $\mathrm{Bcl}-2$ family member $\mathrm{A} 1$ in inhibition of apoptosis in mycobacteria-infected macrophages. IUBMB Life 2015; 67: 726-736.

47. Speir M, Lawlor KE, Glaser SP, Abraham G, Chow S, Vogrin A et al. Eliminating Legionella by inhibiting BCL-XL to induce macrophage apoptosis. Nat Microbiol 2016; 1: 15034.

48. Manzl C, Baumgartner F, Peintner L, Schuler F, Villunger A. Possible pitfalls investigating cell death responses in genetically engineered mouse models and derived cell lines. Methods 2013; 61: 130-137.

49. Roberts AW, Davids MS, Pagel JM, Kahl BS, Puvvada SD, Gerecitano JF et al. Targeting BCL2 with Venetoclax in Relapsed Chronic Lymphocytic Leukemia. N Engl J Med 2016; 374 311-322.

50. Kotschy A, Szlavik Z, Murray J, Davidson J, Maragno AL, Le Toumelin-Braizat G et al. The MCL1 inhibitor S63845 is tolerable and effective in diverse cancer models. Nature 2016; 538: 477-482.

51. Schwenk F, Baron U, Rajewsky K. A cre-transgenic mouse strain for the ubiquitous deletion of loxP-flanked gene segments including deletion in germ cells. Nucleic Acids Res 1995; 23: 5080-5081.

52. Okamoto T, Coultas L, Metcalf D, van Delft MF, Glaser SP, Takiguchi M et al. Enhanced stability of Mcl1, a prosurvival $\mathrm{Bc} 2$ relative, blunts stress-induced apoptosis, causes male sterility, and promotes tumorigenesis. Proc Natl Acad Sci USA 2014; 111: 261-266.

53. Deenick EK, Gett AV, Hodgkin PD. Stochastic model of T cell proliferation: a calculus revealing IL-2 regulation of precursor frequencies, cell cycle time, and survival. $J$ Immunol 2003; 170: 4963-4972.

54. Marchingo JM, Kan A, Sutherland RM, Duffy KR, Wellard CJ, Belz GT et al. T cell signaling Antigen affinity, costimulation, and cytokine inputs sum linearly to amplify $T$ cell expansion. Science 2014; 346: 1123-1127.

55. Karasuyama $\mathrm{H}$, Melchers $\mathrm{F}$. Establishment of mouse cell lines which constitutively secrete large quantities of interleukin 2, 3, 4 or 5, using modified cDNA expression vectors. Eur $J$ Immunol 1988; 18: 97-104.

56. Vremec D, Pooley J, Hochrein H, Wu L, Shortman K. CD4 and CD8 expression by dendritic cell subtypes in mouse thymus and spleen. J Immunol 2000; 164: 2978-2986. 